It has been proposed that a more accurate index of maximum gastric secretory function is the "peak acid output," derived from the maximum post-histamine 30-minute output (Baron, 1962). Nevertheless it has been shown that the one-hour posthistamine acid output (Card and Marks, 1960) has a discriminatory value equal to that of the "peak acid output," and is thus the more practical and preferable index of secretion (de Moura and Correia, 1964). In the present study the peak acid outputs after $100 \mathrm{mg}$. of Histalog correlated very closely with those after histamine acid phosphate $0.04 \mathrm{mg} . / \mathrm{kg}$. However, peak rates of secretion were often delayed until the second hour after the Histalog, which necessitates prolongation of the test compared with the one-hour collection period of the augmented histamine test if this parameter is used.

The practical implication of the present study is that $100 \mathrm{rng}$. of Histalog may usefully replace histamine acid phosphate $0.04 \mathrm{mg} . / \mathrm{kg}$. in the determination of one-hour "maximum" acid outputs. In interpretation it will be possible to use secretory standards previously established for the augmented histamine test (Marks, 1961). Advantages of the use of this standard dose of Histalog are the fewer side-effects, the reduced likelihood of errors in dosage, and the lack of necessity for an antihistamine drug, which itself may produce untoward effects occasionally. In the elderly subject, especially where confirmation of achlorhydria is sought, a one-hour collection after $50 \mathrm{mg}$. of Histalog may be adequate (Ward et al., 1963).

\section{Summary}

In duplicate gastric analyses on 20 patients the mean onehour acid outputs following $100 \mathrm{mg}$. of Histalog (betazole hydrochloride) intramuscularly were comparable to those following a "maximum" dose of histamine. Flushing, headache, and drowsiness were less prominent with Histalog than after maximal histamine stimulation. It is concluded that Histalog $100 \mathrm{mg}$. may usefully substitute histamine acid phosphate $0.04 \mathrm{mg} . / \mathrm{kg}$. in the determination of one-hour maximum acid outputs, and that the results can be interpreted in the light of previously established standards for histamine.

- I am grateful to Dr. Bernard Lake, of Eli Lilly Ltd., Sydney, for generous supplies of Histalog, and to Mrs. C. Wesselingh, S.R.N., for conducting the tests.

\section{REFERENCES}

Baron, J. H. (1962). Proc. roy. Soc. Med., 55, 74

Card, W. I., and Marks, I. N. (1960). Clin. Sci., 19, 147. de Moura, M. C., and Correia, J. P. (1964). Amer. F. dig. Dis., 9, 669. Kirsner, J. B., and Ford, H. (1955). 3. lab. Clin. Med., 46, 307. Marks, I. N. (1961). Gastroenterology, 41, 599.

Ward, S., Gillespie, I. E., Passaro, E. P., and Grossman, M. I. (1963). Ibid., 44, 620 .

Zaterka, S., and Neves, D. P. (1964). Ibid., 47, 251.

\title{
Antibiotics in Recurrent Cholangitis
}

\author{
P. C. REYNELL,* D.M., F.R.C.P.
}

Brit. med. F., 1965, 1, 1288-1289

Repeated rigors, often associated with jaundice and vomiting, in a patient with presumptive biliary disease usually indicate cholangitis due to incomplete obstruction of the common hepatic or common bile-duct. The conventional treatment is surgical. This is right and proper, but occasionally the patient may refuse operation or the surgeon may be unwilling to operate owing to age, infirmity, or technical difficulties. The patient may then be given a short course of chemotherapy, and when the symptoms inevitably recur an attitude of hopelessness is apt to descend on patient and physician alike. This is a report of three such cases apparently cured by a prolonged course of antibiotics.

\section{Case Reports}

Case 1.-A 70-year-old man had cholecystectomy for gall-stones in 1955. Three years later he started to get recurrent attacks of jaundice. These were subsequently associated with rigors, confusion, and incontinence, and jaundice became persistent. When seen at home in 1960 he was weak and wasted, and was given a four-weeks course of tetracycline. A month after treatment he had had no further rigors but was still jaundiced, and liver-function tests showed: serum bilirubin $7.3 \mathrm{mg} . / 100 \mathrm{ml}$., serum alkaline phosphatase 45 K.A. units, plasma proteins normal, S.G.O.T. 180 units. Jaundice progressively faded and an intravenous cholangiogram showed poor visualization of the ducts. When last seen seven months after treatment he appeared to be quite well, with serum bilirubin $0.8 \mathrm{mg} . / 100 \mathrm{ml}$. and serum alkaline phosphatase 14 K.A. units. Four years after treatment he was known to be

* Consultant Physician, Bradford A Group Hospitals. alive and well and had had no further reason to consult his practitioner.

Case 2.-A 74-year-old woman was seen in July 1960 with a history of recurrent abdominal pains for seven years. Latterly these had been associated with irregular rigors, vomiting, and confusion. Short courses of penicillin and chloramphenicol had been ineffective. Liver-function tests were normal except for a serum alkaline phosphatase of 39 K.A. units. She had two further rigors after admission to hospital. There was no filling of the gall-bladder after an oral cholecystogram, but an intravenous cholangiogram showed dilated common and cystic ducts, with a faintly opacified gall-bladder which appeared to contain non-opaque stones. The patient refused operation and was discharged after a 10-day course of sulphamethoxypyridazine. Rigors continued with intermittent jaundice and loss of weight, and she was readmitted in March 1961. A further rigor occurred after admission, when serum bilirubin rose to $3.7 \mathrm{mg} . / 100 \mathrm{ml}$., serum alkaline phosphatase to $87 \mathrm{~K}$.A. units, and thymol turbidity was 7 units. She was regarded as unfit for surgery and discharged. Two months later she was seen at home, having rigors every week. She was disillusioned and depressed, and refused readmission to hospital. Dimethylchlortetracycline $150 \mathrm{mg}$. q.d.s. was given for four weeks, and has been continued thereafter in a dose of $150 \mathrm{mg}$. daily. She has had no further symptoms and was quite well 42 months later.

Case 3.-A 60-year-old man started to complain of recurrent abdominal pain in 1953. Four years later a barium-meal examination showed a small hiatal hernia and distortion of the duodenal cap. In 1959 the hiatal hernia was repaired and a partial gastrectomy was performed. He continued to complain of pain, and a year later developed rigors and vomiting. A cholecystogram showed no filling of the gall-bladder. At operation the bile-ducts were grossly distended and packed with " biliary mud." The gallbladder was removed, a large friable stone was extracted from the 
common duct, and the ducts were irrigated. However, a final cholangiogram taken before removal of the T-tube revealed two further stones and persistent gross dilatation of the ducts (see Fig.). After a few months' remission, pain, vomiting, and rigors recommenced. In November 1962 liver-function tests were normal apart from a serum alkaline phosphatase of 45 K.A. units. Tetracycline $250 \mathrm{mg}$. q.d.s. was given for four weeks without benefit. In March 1963 a liver biopsy showed evidence of biliary cirrhosis and a liver fragment was sterile on culture. He was slightly jaundiced, rigors continued, and a tender liver-edge was palpable $1 \frac{1}{2}$ in. (4 cm.) below the costal margin. Serum bilirubin was $2.4 \mathrm{mg} . / 100 \mathrm{ml}$., serum alkaline phosphatase 156 K.A. units, S.G.O.T. 59 units, serum albumin 2.5 g. $/ 100 \mathrm{ml}$.; serum globulin $4.3 \mathrm{~g} . / 100 \mathrm{ml}$. He was given penicillin (1 mega unit) and streptomycin $(0.5 \mathrm{~g}$.) twice daily for four weeks. Low-grade pyrexia continued for the first two weeks, but symptomatic improvement was immediate. There have been no further rigors or jaundice, although he has occasional acid regurgitations, which have occurred since the operation on the lower oesophagus. In October 1964 the liver was no longer palpable and all liver-function tests were normal.

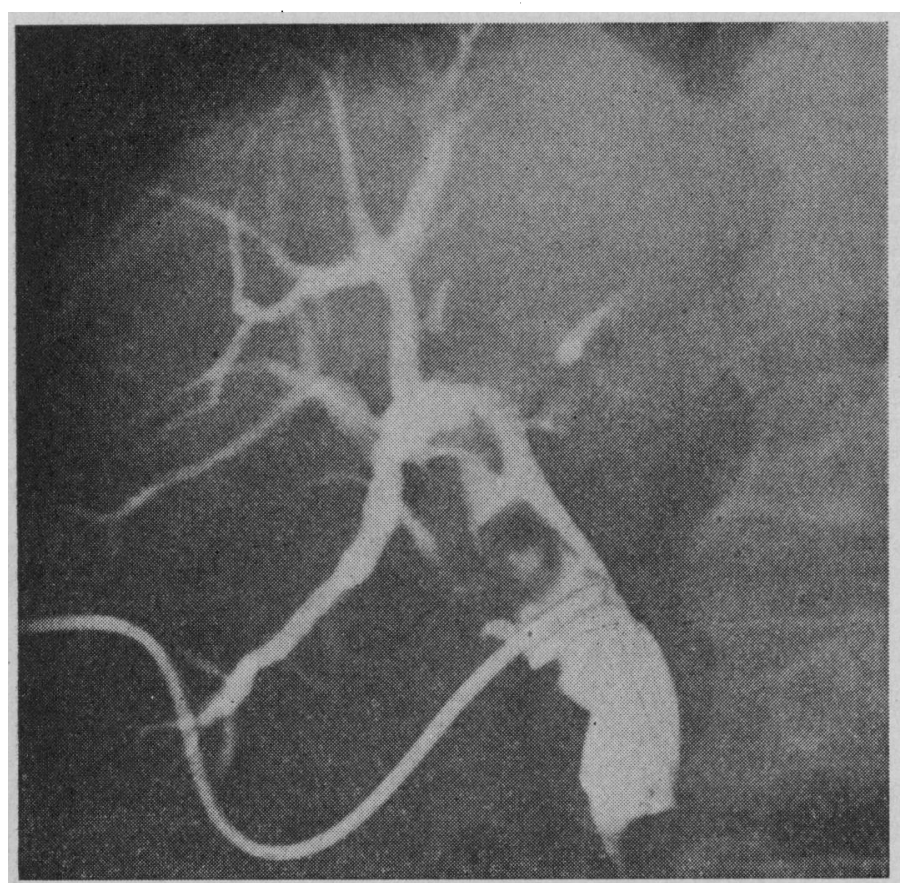

Case 3. Cholangiogram showing two stones and gross dilatation of ducts.

\section{Discussion}

It has long been realized that patients with subacute bacterial endocarditis require prolonged antibiotic therapy, as some inaccessible organisms may survive a short course of treatment. The same principle has gained favour in the treatment of patients with recurrent and chronic urinary infections when there is no obstructive lesion amenable to surgery (Stansfeld and Webb, 1954 ; Rosenheim, 1963). In patients with recurrent or chronic biliary infection any obstructive lesion should, if possible, be relieved surgically. However, this is not always technically feasible and the patient may be unwilling or unfit for operation. The three patients in this series had suffered from Charcot's intermittent fever for periods of 12 to 30 months, and in two of them short courses of chemotherapy had been totally ineffective. All were apparently cured by a course of at least four weeks' antibiotic therapy and had no further rigors after follow-up periods of 48,42 , and 18 months respectively.

The choice of antibiotic may sometimes be determined by isolation of the causative organism on aerobic and anaerobic culture of the blood or of a hepatic fragment obtained by needle biopsy. Escherichia coli and Streptococcus faecalis are common pathogens, for which the tetracycline drugs are usually suitable and have the added advantage that they are excreted in high concentration in the bile (Zaslow et al., 1950). However, a bactericidal drug may be preferred to one which is merely bacteriostatic, and one patient in this series was cured by a long course of streptomycin, with penicillin, when tetracycline had failed.

\section{Summary}

Three patients who had recurrent cholangitis for over a year, and were thought to be unsuitable for surgery, were apparently cured by a four-weeks course of antibiotics and have remained well for one and a half to four years.

I am grateful to Dr. S. Adrian Price for follow-up data on Case 2.

\section{REFERENCES}

Rosenheim, M. L. (1963), Brit. med. ₹., 1, 1433

Stansfeld, J. M., and Webb, J. K. G. (1954). Ibid., 1, 616

Zaslow, J., Hewlett, T. H., and Goldsmith, R. (1950). Gastroenterology, 16, 479.

\section{Preliminary Communications}

\section{Oral Contraceptives and Liver Damage}

Brit. med. F., 1965, 1, 1289-1290

The article by Eisalo, Järvinen, and Luukkainen (1964), in which they described seven cases with signs of impaired liver function after use of an oral contraceptive (Lyndiol), gave rise to the discussion of the possible hepatotoxic effect of these and similar pills. Palva and Mustala (1964), for example, found the same type of liver damage in five women who had been taking Anovlar; Fawcett and Pedersen (1964) in one woman who had been using Anovlar ; and Sotaniemi, Kreus, and Scheinin (1964) following the use of Volidan. On the other hand, such contraceptives have not been found to cause liver damage in large and thoroughly examined series (Swaab, 1964 ; Linthorst, 1964, 1965 ; Tyler, 1964 ; Rice-Wray, 1964).

It has long been known that C 17-alkylated steroids have a hepatotoxic effect (Drill, 1959). Since all contraceptive pills hitherto tried contain steroids of this type, abnormal results of liver-function tests must occasionally be expected. The differences between the frequencies reported in the abovementioned investigations are strikingly large, and the conclusion drawn by Palva and Mustala (1964) on the basis of a small personal series and on that described by Eisalo et al. (1964) that "it leaves no doubt about the hepatotoxicity of this contraceptive pill " is rather surprising.

According to Eisalo et al. it is the oestrogenic component that is hepatotoxic. The oestrogenic hormone combined with progestogen (Lyndiol) produced signs of liver damage in all 